Each ganglion consisted of 8-12 small multipolar cells intermingled with groups of non-myelinated nerve fibres. These structures, being morphologically similar to autonomic ganglia, were regarded as fragments from the plexus on the wall of the internal carotid artery.

A small-celled component near the rostral limit of the abducens nucleus was studied with particular care. The cells here are not representative of firstorder neurones, and their function is not known.

In the cat ${ }^{3}$ and the pig ${ }^{4,5}$ a contribution has been reported from the mesencephalic root of the fifth nerve to the trochlear nerve at its decussation. In the case of the sixth nerve, no similar direct connexion was evident. Investigations are now being carried out concerning a possible connexion between the first division of the trigeminal and the oculomotor nerves in the pig; such a connexion has been observed in man and certain mammals by other workers.

M. E. LAW

M. J. T. FitzGerald

Department of Anatomy,

University College,

Cork.

June 15

${ }^{1}$ Garven, H. S. D., and Gairns, F. W., Quart. J. Exp. Physiol., 37, 131 (1952).

2 Nicholson, H., J. Comp. Neurol., 3\%, 31 (1924).

s Tarkhan, A. A., J. Anat., 64, 112 (1934).

- Kane, F., and Law, M. F., Nature, 172, 1049 (1953).

s Law, M. E., Ir. J. Med. Sci., 362, 68 (1956).

\section{Milk Production and Interval between Milking}

Is a recent communication ${ }^{1}$ results were presented challenging the generally accepted theory that secretion-rate in the dairy cow declines with time in the interval between successive milkings. These Ruakura experiments showed that secretion-rate was constant up to $20-24 \mathrm{hr}$. It was suggested that, under a twire-a-day milking regime, unequal intervals of considerable magnitude might be employed without any significant difference in milk yield due to direct pressure effects.

An experiment to test this has recently been completed at Ruakura. The work extended over two years. In the first year seven sets of monozygotic twins and in the second year eleven sets were milked such that one member of each pair was milked at equal 12-hr. intervals and the other member at intervals of 8 and $16 \mathrm{hr}$.

Mean productions for the complete lactations were :

\begin{tabular}{|cc|c|c|c|c|}
\hline & Ycar & No. of sets & \multicolumn{1}{c|}{ Milk } & Fat & Days \\
\hline $12-12$ & $1954-55$ & 7 & $5628 \cdot 3$ & $252 \cdot 4$ & 232 \\
$16-8$ & & $5461 \cdot 4$ & $246 \cdot 1$ & 232 \\
$12-12$ & $1955-56$ & 11 & 6438 & 316 & 264 \\
$16-8$ & & & 6555 & 321 & 264 \\
\hline
\end{tabular}

These results are not only of obvious theoretical interest but also have important implications for the dairy industry.

Ruakura Animal Research Station,

C. P. MoMegkan

P. J. BRUMbY

Hamilton, New Zealand.

1 Elliott, G. M., and Brumby, P. J., Nature, 176, 350 (1955).
Preferential Uptake of Sulphone by Affected Skin Tissue of Leprosy Patients as detected by a Tracer Method

DIAMINO-DIPHENYL-SULPHONE and a number of its derivatives have been found to be very effective in the treatment of leprosy; but the exact mode of their action on the affected tissue and invading Mycobacterium has not yet been definitely established ${ }^{1-3}$. In the present work, diamino-diphenylsulphone labelled with sulphur-35 was used for studying the time variation of concentration of the drug in blood and healthy and diseased skin tissues of the leprosy patients. An interesting observation was that the drug was found to be localized to a greater extent in the affected tissues compared to healthy ones. Such studies were not possible with the help of earlier colorimetric techniques ${ }^{4}$, as these required tissues in bulk. The method used here was found to be ten times more sensitive than the colorimetric techniques.

Diamino-diphenyl-sulphone labelled with sulphur35 (procured from the Atomic Energy Research Fstablishment, Fngland) was administered to nine patients as a single oral dose of $4 \mu \mathrm{c} . / \mathrm{kgm}$. bodyweight. The specific activity of the drug was about 0.75 uc./mgm. After administration of diaminodiphenyl-sulphone, samples of skin tissues were removed by biopsy from affected sites as well as from adjacent healthy sites, at different intervals. These were finely minced and homogenized with distilled water. The suspension was then uniformly spread over previously weighed copper planchets and dried under an infra-red lamp. Simultaneously with skin samples, blood was also collected from each patient. 0.1 c.c. of blood was similarly dried on the pre-weighed copper planchets. The planchets were reweighed to get the thickness of the sample in $\mathrm{mgm} . / \mathrm{cm} .{ }^{2}$. The thickness of the deposits varied from 4-6 mgm. $/ \mathrm{cm}^{2}$. They were placed under a previously calibrated end-window Geiger-Müller counter (window thickness $2.8 \mathrm{mgm} . / \mathrm{cm} .{ }^{2}$ ) and the activity of the sample was deduced from the recorded number of counts per minute and the sample thickness ${ }^{5}$.

The concentration of diamino-diphenyl-sulphone (sulphur-35) in the blood, healthy and affected skin tissues of the leprosy patient is shown in Table 1. It is apparent from the table that the concentration in the healthy skin runs almost parallel to the concentration in blood. Within an initial period of $6 \mathrm{hr}$. after administration, concentration in blood seems to be $2-3$ times that in the healthy skin. If, however, a comparison be made of the concentration of the

Table 1. Variation of the Concentration of Diamino-Dipheny Table 1. VARIATION OF THE CONCENTRATION OF DIAMD TISSUES
SULPHON IN BLOOD, HEALTHY AND AFFECTED TIS

\begin{tabular}{|c|c|c|c|c|}
\hline \multirow[b]{2}{*}{ Patient } & \multirow{2}{*}{$\begin{array}{l}\text { Hours } \\
\text { after } \\
\text { adminis- } \\
\text { tration }\end{array}$} & \multicolumn{3}{|c|}{$\begin{array}{l}\text { Concentration of diamino-diphenyl- } \\
\text { sulphone (in } \mu \mathrm{c} . / \mathrm{gm} \text {.) in }\end{array}$} \\
\hline & & Blood & Healthy skin & Affected skin \\
\hline \multicolumn{3}{|c|}{ Nature of lesion: single } & & \\
\hline M. H. & $6 \mathrm{hr}$. & $0.035 \pm 0.002$ & $0 \cdot 013 \pm 0 \cdot 003$ & $0 \cdot 143 \pm 0 \cdot 007$ \\
\hline P. M. & 18, & $0.019 \pm 0.002$ & $0 \cdot 014 \pm 0 \cdot 003$ & $0 \cdot 140 \pm 0.006$ \\
\hline G. $\frac{H}{\mathrm{~S}}$. & 24, & $\begin{array}{r}0.008 \pm 0.003 \\
0+0.001\end{array}$ & $\begin{array}{r}0.009 \pm 0.003 \\
0 \pm 0.001\end{array}$ & $\begin{array}{l}0.084 \pm 0.006 \\
0.010 \pm 0.003\end{array}$ \\
\hline \multicolumn{3}{|c|}{ Nature of lesion : multiple } & & \\
\hline B. M. & $6 \mathrm{hr}$. & $0 \cdot 036 \pm 0 \cdot 002$ & $0 \cdot 016 \pm 0 \cdot 003$ & $0.067 \pm 0.005$ \\
\hline M. Y. & 18, & $0 \cdot 008 \pm 0 \cdot 003$ & $0 \cdot 005 \pm 0 \cdot 002$ & $\begin{array}{l}0.064 \pm 0.005 \\
0.083 \pm 0.006\end{array}$ \\
\hline $\begin{array}{l}\text { B. D. } \\
\text { J. S. }\end{array}$ & 24, & $\begin{array}{r}0.010 \pm 0.003 \\
0 \pm 0.001\end{array}$ & $\begin{array}{r}0.000 \pm 0.001 \\
0 \pm 0.001\end{array}$ & $0 \cdot 004 \pm 0.001$ \\
\hline & $144 "$, & $0 \pm 0.001$ & $0 \pm 0 \cdot 001$ & $0.005 \pm 0.002$ \\
\hline
\end{tabular}

$N . B$. The errors indicated in this table are the standard errors of beta-counting only. 